\title{
Creating Shared Value and Fan Loyalty in the Korean Professional Volleyball Team
}

\author{
Sang-soo Kim ${ }^{1}$, Woo-yeul Baek ${ }^{2, * \mathbb{C}}$, Kevin K. Byon ${ }^{3} \mathbb{C}$ and Sung-bum Ju ${ }^{4}$ \\ 1 School of Physical Education, Keimyung University, Daegu 42601, Korea; ks1114@kmu.ac.kr \\ 2 Department of Sport Management, Kyonggi University, Gyeonggi-do 16227, Korea \\ 3 Department of Kinesiology, Indiana University-Bloomington, Bloomington, IN 47405, USA; \\ kbyon@indiana.edu \\ 4 Department of Physical Education, Busan National University of Education, Busan 47503, Korea; \\ accent@bnue.ac.kr \\ * Correspondence: wyb71@kyonggi.ac.kr
}

Received: 1 August 2020; Accepted: 14 September 2020; Published: 16 September 2020

\begin{abstract}
Creating shared value has been a new strategic management paradigm for professional sport teams around the world. However, despite the active participation of professional sport teams in creating a shared value program, research that addresses its effectiveness appears to be very limited. The present study investigates the influence of sport fans' perceived creating shared value on team trust and fan loyalty and the moderating effects of sport fans' altruism on the relationship between creating shared value and team trust in the Korean professional volleyball league. A total of 198 Korean volleyball fans participated in the present study. Results revealed that sport fans' perceived economic and social values had significant impacts on team trust and, in turn, team trust significantly affected fan loyalty. However, the moderating effect of sport fans' altruism was not found on the relationships between creating shared value and team trust. Consequently, the present study's findings may provide professional sport teams' marketers with the rationale as to the effectiveness of launching creating shared value programs.
\end{abstract}

Keywords: creating shared value; team trust; fan loyalty; altruism; professional sport

\section{Introduction}

Firms have embraced corporate sustainability management concepts, which generate long-term business sustainability in the economic, environmental, and societal circumstances [1]. Especially, as consumers' interests in realizing corporate social values and enhancing management transparency have increased, many firms have adopted corporate social responsibility as part of their management strategies. According to the 2014 Public Affairs Pulse Survey, it is found that $84 \%$ of consumers in the United States are more likely to be interested in social issues, and also expect real social responsibility from these companies shortly [1]. Another survey also reported that more than half (55\%) of consumers worldwide who responded to the survey are willing to pay extra for products and services from companies that launched corporate social responsibility programs if their purchase can have positive social and environmental impacts [2]. As reflected in this trend, about $75 \%$ of the 4900 companies worldwide participating in practical social responsibility activities have revealed that the annual report on their social responsibility activities to the public [3].

Although corporate social responsibility activities have entered the stage of quantitative expansion, questions are raised about the company's simple donation activities' effectiveness to solve social and environmental problems [4]. In other words, because a firm is an economic organism that represents the interests of various stakeholders, it can only implement limited social responsibility activities with 
the unilateral sacrifice of shareholders and employees. It should shift to strategic social responsibility management that can represent the interests of all stakeholder groups [5]. In this regard, Porter and Kramer [6] introduced the concept of creating shared value and suggested that a firm interdependent with the community should create a virtuous cycle promoting its business growth by connecting the business operations with various social problems to realize its sustainable development. As a result, creating shared value is a new strategic management paradigm for a firm to secure sustainable competitiveness by taking the financial obligation of maximizing profits and the role of a corporate citizen in solving social problems faced with society [7].

The application of creating shared value programs in the management strategy of a company reflects consumers' demand for the ethical responsibility of a so-called "good company." Today's consumers can be influenced by the moral value of brands along with traditional product attributes, such as price and quality, in their purchase decisions. For example, consumers boycotted Shell Oil because it decides to sink the Brent Spar oil rig, and Nestle lost its reputation after selling inappropriate milk to pregnant women in developing countries [8,9]. Similarly, Korean companies that caused public criticism due to sexual harassment and drug-taking of the CEOs and assault of the owner's family also reported cases where sales fell by $20-40 \%$ [10]. Therefore, it seems that a firm needs to create consumers' trust in the firm as an excellent company to secure the effectiveness of its developing shared value programs.

Research on the effectiveness of corporates' creating shared value activities has been actively conducted in the general marketing field. Most studies reported that consumers' perception of firms' creating shared value programs mainly influences attitude toward a brand [11,12], brand trust and image creation [13-16], and brand loyalty [14,17]. In particular, Won and Jung [16] reported that the economic, social, and cultural effects of creating shared value activities have positive impacts on brand image and trust. They concluded that a long-term approach is necessary for a firm's creating shared value to enhance a favorable image and trust of the brands from consumers. $\mathrm{Na}$, Lee, and Han [18] also found that consumers' positive perceptions of the hotel industry's creating shared value activities enhance its brand image and customer loyalty. The researchers also reported the positive mediating effect of brand image in the relationship between consumers' perceptions of creating shared value and customer loyalty. However, these existing studies regard consumers with various psychological characteristics as a single consumer group and, thus, seem to have limitations in explaining firms' creating shared value activities on consumption behavior.

Altruism inherent in consumers has been suggested as an essential psychological factor in determining purchasing behavior related to the effectiveness of corporate social contribution activities $[19,20]$. In general, altruism means an individual's intrinsic psychological tendency to help others without any external compensation [21]. Highly altruistic consumers tend to respond more positively to corporate social responsibility activities and care to help others more often than non-altruistic consumers [22]. For example, Lavack and Kropp [19] reported that consumers who are more interested in philanthropic activities value positive relationships with others and show a more positive attitude toward corporate social responsibility activities. Vlachos [20] also argued that in a comparative study with consumers with low altruism, highly altruistic consumers tend to show behaviors that help others and purchase products related to corporate social responsibility activities. Therefore, to fully identify the effectiveness of a firm's creating shared value program from the perspective of consumer behavior, a study on the issue must consider consumers' inherent altruistic tendencies.

Meanwhile, professional sport teams have actively participated in creating shared value programs. For example, the Seattle Mariners of the American Major League Baseball League partnered with a local recycling company that hires local recovering addicts to process and recycle waste at the stadium, strengthening the team's brand [23]. Moreover, as part of the creating shared value activities, SK Knights, one of the professional basketball teams in Korea, launched the Silver Challenger program, which provides the retired elderly in the community with a job to inspect game tickets and guide 
seats [24]. However, despite the active participation of professional sport teams around the world in creating a shared value program, research related to its activity appears to be very limited. Therefore, the present study examined the influence of sport fans' perceived creating shared value programs of a professional sport team on team trust and fan loyalty, and the moderating effects of sport fans' altruism on the relationships between creating shared value and team trust in the context of the Korean professional volleyball league.

\section{Theoretical Background and Hypothesis Development}

\subsection{Creating Shared Value and Brand Trust}

Creating shared value refers to management activities that strengthen the competitive advantage by realizing companies' traditional economic value and social value that participate in solving social problems [6]. According to Porter and Kramer [6], firms should address social issues by reorganizing their business model that reflects both societal needs and the firm's internal economic value. For example, in 2010, a global food company, Nestle, launched the Nescafe Plan, which provided its coffee farmers with high-quality coffee seedlings resistant to pests and training programs for coffee cultivation and living environment [25]. Through this program, Nestle provided an average of 26.8 million seedlings to the coffee farms, and stably received 225,600 tons of coffee beans. Besides, Adidas, a global sporting goods company, also partnered with the marine environmental protection group Parley for the Oceans and introduced shoes that recycle marine waste and illegal deep-sea gillnets from yarn and filament uppers [26]. Given this, studies on creating shared value have shed light on the differences between corporate social responsibility and creating shared value $[27,28]$ and the links of consumers' creating shared value perceptions with customer behavior and firm performance [29-31].

Moreover, since most professional sport teams are operated based on a local franchise system representing specific regions, community popularity and support is essential for financial success. Although a professional sport team is a for-profit business entity, and its basic business plan is the same as other popular forms of audience-driven entertainment, it is a special kind of business because it builds ongoing relationships with its fans. Therefore, it makes the fans feel treasured and yearn to visit the venue over and over. From the perspective of sustainable growth, the strategic linking of social problem-solving in carrying out the business activities of a professional sport team is an important management strategy to build trust and support from the local people. When constructing a new $\$ 1.2$ billion worth stadium in 2014, the National Football League's Atlanta Falcon launched the Equal Business Opportunity Plan, which partnered with minority and women-owned business enterprises in the community during the design and construction phase of the stadium. This initiative created a shared value that helps Atlanta residents and business ecosystems [32]. Besides, The Korea professional volleyball league's Hyundai Capital realized creating shared value by partnering with local small businesses and providing business rights to develop and sell the team's character products [33]. Collectively, professional sport teams' creating shared value, which deviates from the existing paradigm of fulfilling social responsibilities through charity activities, seek sustainable growth by securing management efficiency that promotes local communities' development and the expansion of sport fan base.

Most studies on the effectiveness of creating shared value have reported that the firms' creating shared values programs based on consumer perception affects brand trust [14,34,35]. In general, brand trust refers to the belief that a company will launch and provide goods and services that meet customer needs and desires [36]. As well, consumers' trust in a brand can be regarded as a corporate reputation, which also means that consumers believe in the company, trusting in the expertise to deliver quality products promised by the brand [37]. Building trust from consumers, primarily, can act as a more critical factor than functional factors such as price and quality when consumers decide to purchase goods or services [38]. Consumers' trust in a brand is the basis for positive relationships between consumers and companies, and ultimately, consumers' trust is essential for the sustainable 
growth of companies in the market [39]. In this regard, Park and Lee [34] reported that airline users' perceived economic value, which is a sub-category of creating shared value, has a positive effect on brand trust. The researchers concluded that when airline customers perceive good quality service and reasonable prices, airline users are likely to build brand trust. In a study related to the effectiveness of banks' creating shared value, Lee [35] found that creating shared value programs perceived by bank users have a positive effect on corporate image and trust. The scholar argued that creating shared value activities are the core competencies for firms' sustainable competitive advantage. Kang [14] reported that consumers' perception of social value for social enterprise positively influenced brand trust and reputation. Kang suggested that creating shared value programs for social enterprise can be differentiating strategies for sustainability. Thus, based on the findings of previous relevant studies, the following hypothesis was posited:

Hypothesis 1 (H1). The economic value of a professional volleyball team's creating shared value program perceived by sport fans will have a positive effect on team trust.

Hypothesis 2 (H2). The social value of a professional volleyball team's creating shared value program perceived by sport fans will have a positive effect on team trust.

\subsection{Brand Trust and Brand Loyalty}

From a firm's viewpoint, customer loyalty, which refers to consumers' psychological attachment to their favorite brand [40], is a crucial factor that can realize brand differentiation in today's competitive market environment and can be an important outcome variable for brand assets [36]. Since consumers with high customer loyalty have a strong tendency to function as loyal consumers through repeated purchases and positive word-of-mouth for specific brands, firms can expect increased sales, reduced marketing costs, and enhanced market share [41,42]. Looking at the research related to corporates' creating value creation, Park, Kang, and Lee [12] reported that consumer perceptions of creating shared value of catering companies have a positive effect on brand trust, and, in turn, brand trust ultimately influences purchase intention. Moon and Kim [43] also reported that cognitive and emotional trust based on creating shared value programs positively affected customer loyalty and concluded that brand trust is a crucial antecedent of brand loyalty. Similarly, Kang [14] also reported that consumers' trust toward a social enterprise positively impacts brand loyalty. Thus, the following hypothesis was proposed based on prior studies on the effectiveness of firms' creating shared value programs:

Hypothesis 3 (H3). Team trust of sport fans toward a professional volleyball team will have a positive effect on fan loyalty.

\subsection{Moderating Effects of Altruism}

Altruism refers to the psychological tendency to help others without external rewards and acts as an internal motivation to help others [21]. In general, human altruistic behavior manifests itself in the form of monetary donations or volunteering to charities. Scholars suggest altruism as a crucial psychological characteristic that affects the purchase behavior of consumers [44]. Highly altruistic consumers are more likely to help others than those with low altruism. As well, consumers with high altruism tend to respond more positively to the advertisements of products containing environmental protection messages and purchase those products more than their counterparts [45,46]. Unfortunately, there is a scarcity of research on the relationship between firms' creating shared value and consumers' altruism to date. However, according to Gupta and Pirsch [47], the more consumers perceive a company's corporate social responsibility campaign as having altruistic motives to solve social problems, the higher their willingness to participate in the firm's social responsibility campaign and 
more favorable attitude toward the firm. Lavack and Kropp [19] reported that when consumers have higher levels of psychological involvement in a company's social responsibility campaign, they value self-satisfaction and social relationships more than those with low involvement. As well, the researchers found that consumers with high involvement showed a more positive attitude toward corporate social responsibility compared to those with low involvement in the campaign. Thus, based on the previous studies, we proposed the following hypothesis (see also Figure 1 for the research model):

Hypothesis 4 (H4). The altruism of sport fans will have a positive moderating effect on the relationships among perceived economic and social value of creating shared vale program performed by a professional volleyball team and team trust.

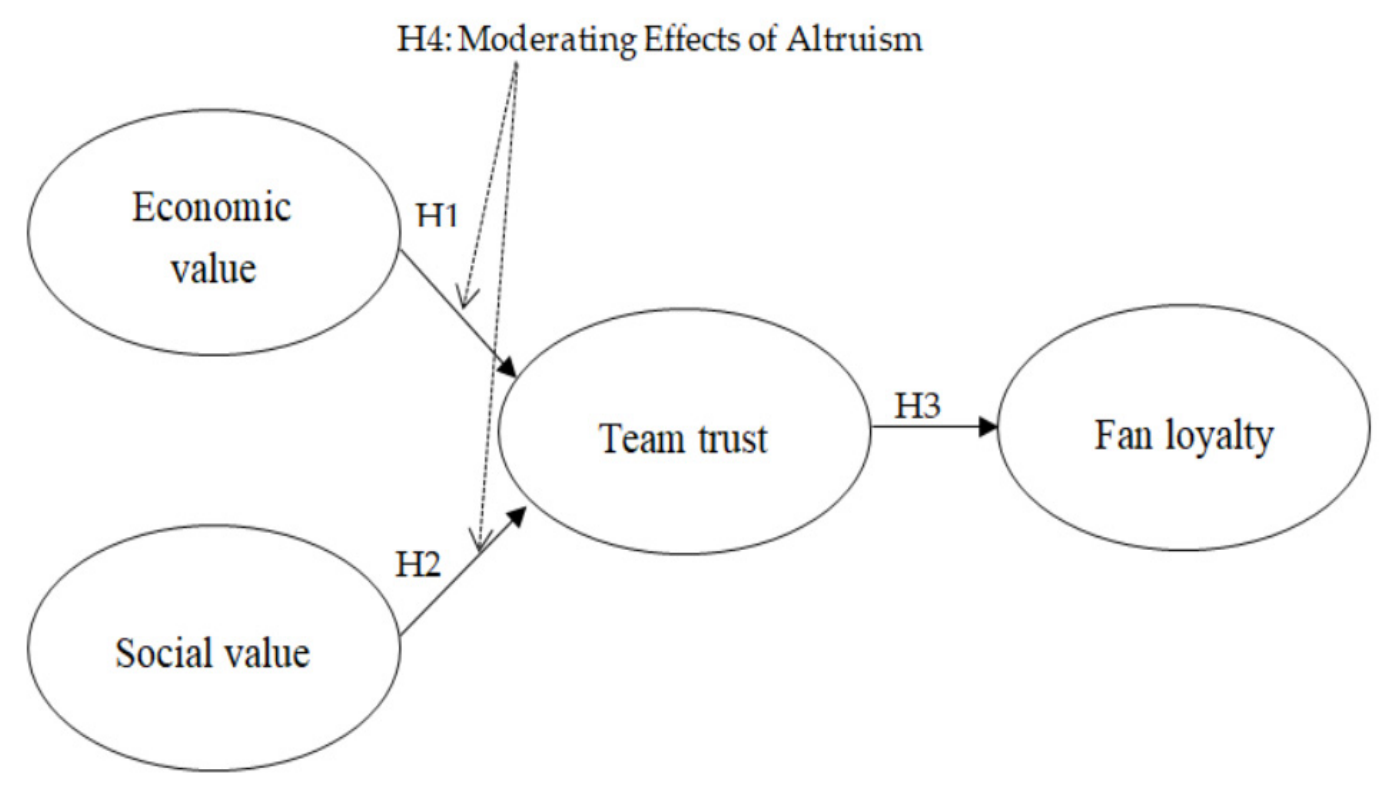

Figure 1. Research Model.

\section{Method}

\subsection{Participants and Data Collection Procedures}

Data were collected from spectators who attended a Korean professional volleyball game in November 2019. Four well-trained surveyors spread across the volleyball stadium and collect data from the spectators waiting for the game to start in the stadium seats, hallways, and concession areas. The surveyors confirmed that over the past 12 months, the spectators attended a live professional volleyball game at least once and their willingness to participate in the study before distributing a written consent form. After obtaining their written consent to participate in the survey, the surveyors asked participants to carefully read the written stimulus to create a shared value program of team A used in the current study (in Korean). After reading the scenario carefully, the participants were asked to answer the survey items using a self-administered method. Besides, the scenario, which was shown on the first page of the survey, provided information about the creating shared value program of team A partnering with the local small businesses and giving them business rights to develop and sell the team's character products. More specifically, the stimulus included the following information:

"Professional volleyball team A has signed a business contract with the local advertising marketing agency $B$ as part of its creating shared value program to promote the local businesses and the team's shared growth. According to the contract, agency B will have business rights to develop and sell the team's characters for two years." 
We collected 200 survey questionnaires and eliminated four responses with more than three questions unanswered. As a result, a total of 198 responses were included in the study. Of the study participants, 137 participants $(69.2 \%)$ were male, and 61 participants $(30.8 \%)$ were female. Most of the participants $(50.5 \%)$ fall into the age category of $20-29$ years, and college graduated $(39.9 \%)$. Moreover, $44.9 \%$ of participants reported monthly incomes of below $\$ 2000$, and $40.9 \%$ were students. The summary of demographics was presented in Table 1.

Table 1. Demographics of Participants.

\begin{tabular}{|c|c|c|c|c|c|}
\hline Variables & Categories & Frequency (\%) & Variables & Categories & Frequency (\%) \\
\hline \multirow[t]{4}{*}{ Gender } & Male & $137(69.2 \%)$ & Occupation & Student & $97(49.0 \%)$ \\
\hline & Female & $61(30.8 \%)$ & & Self-employed & $24(12.1 \%)$ \\
\hline & & & & Government officer & $12(6.1 \%)$ \\
\hline & & & & Office worker & $57(28.8 \%)$ \\
\hline \multirow[t]{6}{*}{ Age } & Below 20 & $19(9.6 \%)$ & & Housewife & $8(4.0 \%)$ \\
\hline & 20-29 & $100(50.5 \%)$ & & & \\
\hline & $30-39$ & $49(24.7 \%)$ & Monthly income & Below \$2999 & $89(44.9 \%)$ \\
\hline & $40-49$ & $20(10.1 \%)$ & & $\$ 3000-4999$ & $64(32.3 \%)$ \\
\hline & $50+$ & $10(5.1 \%)$ & & $\$ 5000-6999$ & $35(17.7 \%)$ \\
\hline & & & & More than $\$ 7000$ & $10(5.1 \%)$ \\
\hline \multirow[t]{4}{*}{ Education } & High school & $46(18.2 \%)$ & & & \\
\hline & College student & $51(25.8 \%)$ & & & \\
\hline & College graduate & $79(39.9 \%)$ & & & \\
\hline & Advanced degree & $22(11.2 \%)$ & & & \\
\hline
\end{tabular}

Additionally, the mean value of responses to the survey items of altruism was 3.61. Using a mean split method, the subjects who revealed the average value of less than 3.61 were defined as the low altruistic group $(N=86)$, and those who showed the average value of 3.61 or higher were defined as the high altruistic group $(N=112)$.

\subsection{Instruments}

A total of 20 question items, except five demographic characteristics (i.e., gender, age, education, occupation, monthly income), was adapted from previous studies and measured on a 5-point Liker-type scale ranging from 1 (strongly disagree) to 5 (strongly agree). We adapted six items to measure volleyball fans' perceived creating shared value consisted of economic value ( 3 items, $\alpha=0.78$ ) and social value ( 3 items, $\alpha=0.75$ ) and three items to measure team trust $(\alpha=0.77)$ from Seo [48]. For fan loyalty, three items $(\alpha=0.75)$ were adapted from Kim, Byon, Yu, Zhang, and Kim [49]. Three items to measure altruism $(\alpha=0.85)$ were adapted from Rushton, Chrisjohn, and Fekken [50]. More specifically, the items measuring sport fans' altruism include "I have given money to a charity," "I have donated goods or clothes to a charity," and "I have done volunteer work for a charity."

\section{Results}

\subsection{Descriptive Statistics}

Before testing the research hypotheses, we tested normality, multicollinearity, and outliers. As for outlier using the boxplot, no extreme scores were found in the data set. Descriptive statistical analyses showed the skewness (ranging from -0.36 to -1.02 ) and kurtosis (ranging from 0.21 to 2.13 ) values within the acceptable ranges [43]. Tolerance (ranging from 0.74 to 0.83 ) and variance inflation factor (ranging from 1.20 to 1.38) values were examined to check multicollinearity, and the results revealed that multicollinearity was not a concern [51]. Table 2 shows descriptive statistics and correlations. 
Table 2. Descriptive Statistics and Correlations of Variables.

\begin{tabular}{ccccccccc}
\hline Factors & $\mathbf{M}$ & SD & Skewness & Kurtosis & $\mathbf{1}$ & $\mathbf{2}$ & $\mathbf{3}$ & $\mathbf{4}$ \\
\hline 1. Economic value & 4.24 & 0.64 & -0.87 & 1.62 & 1 & & & \\
2. Social value & 3.92 & 0.75 & -1.02 & 2.13 & $0.27^{* *}$ & 1 & & \\
3. Team trust & 4.10 & 0.65 & -0.65 & 0.62 & $0.41^{* *}$ & $0.40^{* *}$ & 1 & \\
4. Fan loyalty & 3.52 & 0.75 & -0.36 & 0.21 & 0.05 & $0.13^{* *}$ & $0.19^{* *}$ & 1 \\
\hline \multicolumn{7}{l}{ Note. $M=$ mean, $S D=$ standard deviation, ${ }^{* *} p<0.01}$.
\end{tabular}

\subsection{Measurement Model Test}

The results of a confirmatory factor analysis (CFA) revealed an acceptable model fit $\left(\chi^{2}=68.47\right.$, $d f=48, p=0.03, \chi^{2} / d f=1.43$, goodness of fit index [GFI] $=0.95$, root mean square error of approximation $[$ RMSEA $]=0.05$, and standardized root mean square residual [SRMR] $=0.05)$ [52]. We also calculated composite reliability (CR) values (ranging from 0.79 to 0.86 ) and average variance extracted (AVE) values (ranging from 0.56 to 0.69 ), demonstrating good convergent validity [52]. All AVE values were higher than the squared correlation of all configuration pairs, ensuring discriminant validity [52] (see factors loading in Table 3).

Table 3. Factor Loadings ( $\lambda$ ), Composite Reliability (CR), and Average Variance Extracted (AVE).

\begin{tabular}{|c|c|c|c|c|c|}
\hline Variables & Items & $\lambda$ & CR & AVE & $\alpha$ \\
\hline \multirow{3}{*}{ Economic value } & Team A is constantly improving its service performance. & 0.65 & 0.86 & 0.69 & 0.78 \\
\hline & Team A is working to improve financial performance. & 0.78 & & & \\
\hline & Team A is contributing to the development of the local economy through profit creation. & 0.78 & & & \\
\hline \multirow[t]{2}{*}{ Social value } & Team A understands the needs of the local community. & 0.83 & & & \\
\hline & Team A uses the right amount of profit to solve the problems facing the community. & 0.51 & & & \\
\hline Team trust & Team A is a trustworthy professional volleyball team. & 0.69 & 0.85 & 0.66 & 0.77 \\
\hline \multirow{3}{*}{ Fan loyalty } & I will attend team A's game again in the near future. & 0.69 & 0.79 & 0.56 & 0.75 \\
\hline & I will attend at least one more team A's game held in another city. & 0.87 & & & \\
\hline & I will attend Team A's game held in another city in the future. & 0.60 & & & \\
\hline
\end{tabular}

\subsection{Structural Model Test}

As shown in Table 4, the results of structural equation modeling (SEM) revealed an adequate model fit to the data $\left(\chi^{2}=68.81, d f=50, p=0.40, \chi^{2} / d f=1.38\right.$, GFI $=0.94$, RMSEA $=0.04$, and SRMR $\left.=0.05\right)$. Besides, both perceived economic $(\beta=0.38, p<0.001)$ and social values $(\beta=0.35, p<0.001)$ had significant positive impacts on team trust and, in turn, team trust had a significant positive effect on fan loyalty $(\beta=0.21, p<0.05)$. Thus, the research Hypotheses $1-3$ were well supported.

Table 4. Path Coefficients between CRM Motive, Fan Attitude, and Purchase Intention.

\begin{tabular}{ccccc}
\hline & Path & $\boldsymbol{\beta}$ & $\boldsymbol{S E}$ & $\boldsymbol{p}$ \\
\hline H1 & Economic value $\rightarrow$ Team trust & 0.38 & 0.11 & 0.001 \\
H2 & Social value $\rightarrow$ Team trust & 0.35 & 0.07 & 0.001 \\
H3 & Team trust $\rightarrow$ Fan loyalty & 0.21 & 0.10 & 0.05 \\
\hline
\end{tabular}

\subsection{Multiple Group Analysis}

To test if sport fans' embedded altruism moderates the relationships between economic and social values and team trust, we performed multiple group analyses. As shown in Table 5, the results showed that the moderating effect of sport fans' altruism was not found on the relationships between economic value and team trust $\left(\Delta \chi^{2}=1.12, p=0.001\right)$ and social values and team trust $\left(\Delta \chi^{2}=0.01, p=0.001\right)$. Thus, Hypothesis 4 was rejected. 
Table 5. The Results of Moderating Effects of Altruism.

\begin{tabular}{cccccc}
\hline \multirow{2}{*}{ Path } & \multirow{2}{*}{$\Delta \chi^{2}$} & \multicolumn{4}{c}{ Path Coefficients } \\
\cline { 3 - 6 } & & \multicolumn{1}{c}{ High Altruistic Group } & Low Altruistic Group \\
\cline { 3 - 6 } & & $\boldsymbol{\beta}$ & $S E$ & $\boldsymbol{\beta}$ & $S E$ \\
\hline Economic value $\rightarrow$ Team trust & 1.12 & $0.47^{* * *}$ & 0.15 & 0.21 & 0.14 \\
\hline Social value $\rightarrow$ Team trust & 0.01 & $0.27^{*}$ & 0.10 & $0.46^{* *}$ & 0.08 \\
\hline Note: & $*<0.05^{* *} p<0.01^{* * *} p<0.001$.
\end{tabular}

\section{Discussion}

The present study examined the influence of sport fans' perceived creating shared value programs of a professional sport team on team trust and fan loyalty. As well, the moderating effect of sport fans' altruism on the relationship between creating shared value and team trust was investigated in the context of the Korean professional volleyball league. First, this study revealed that sport fans' perceived economic value positively influenced brand trust and is in line with previous studies [12,13,53]. Park et al. [12] found that consumers' trust toward a firm realizing creating shared value activities had positively affected brand attitude and purchase intention, supporting the current study's findings. In addition, Ahn and Han [13] reported that hotel consumers' perceived social value, which is a sub-factor of creating shared value, had a positive effect on brand-consumer identification and brand trust. The researchers found that hotel consumers' perceived authenticity of the creating shared value program had a positive moderating influence in the relationship between these two variables. It seems plausible that if sport fans perceived a professional sport team's creating shared value program as creating economic and social values for the community and the team, they are likely to build trust toward the team. Therefore, to realize creating shared value as part of a sustainable management strategy, professional sport teams need to identify social problems that sport fans sympathize with and apply it to a creating shared value program.

The study also found that sport fans' team trust significantly affected fan loyalty toward the professional volleyball team launching a creating shared value program and replicating previous studies indicating the positive impacts of consumers' brand trust on customer loyalty $[12,14,53]$. In line with the findings of the current study, Moon and Kim [43] reported that consumers' cognitive and emotional trust toward a big retail store launching a creating shared value program positively affects customer loyalty. In a study examining creating shared value for an exhibition and convention center, Park and Kim [54] found that the emotional brand attachment of visitors positively affected brand trust and brand loyalty. They argued that brand trust was an essential antecedent of visitors' brand loyalty, supporting the findings of the present study. Consumers show their trust toward a brand and have a long-term relationship with the brand when they believe that the brand can keep its stated promise $[55,56]$. Likewise, it is possible if fans are aware of a professional sport team's shared value activities that can benefit the local community, they are likely to show their trust toward the team, which would be a foundation for fans' commitment to the team.

Lastly, the present study revealed that sport fans' altruism does not have any moderating effects on the relationship between a professional sport team's creating shared value and team trust. More specifically, sport fans' altruistic tendency did not strengthen both economic and social values on team trust in the current study. The findings of the present study are not in line with Gupta and Pirsch's [47] results. This indicates that the more consumers perceive that firms have an altruistic motive to participate in solving social problems through corporate social responsibility (CSR) activities, the higher their willingness to participate in the CSR, and the more positively they create attitude toward the firms. As well, Lavack and Kropp [19] reported that consumers with high levels of psychological involvement in CSR initiatives tended to perceive relationships with others more importantly than consumers with low levels of involvement. Our study's findings seem attributable to 
information asymmetry between professional sport teams and sport fans and can be explained by the accessibility-diagnosticity model (ADM) theory of Felman and Lynch [57].

According to the ADM theory, when consumers perceive stimuli from outside, they can first recall the most easily accessible information in their memory. Among the recalled information, the consumers come up with a set of alternatives that possibly solve a problem and select the option with the highest reliability and validity, enhancing the information diagnosticity. It is possible that if fans have limited information on shared value creation activities by a professional sport team, they are likely to build trust in the team based on the team's general information, which is more accessible and diagnostic in their memory. It is also plausible that, even for fans with high altruism, when the diagnosticity of information on social value creation through a creating shared value program (e.g., promoting local economy) is recognized as low, fans' embedded altruism may not strengthen the relationship between creating shared value and team trust. Therefore, the marketing managers of professional sport teams should implement communication campaigns that can specifically introduce the purpose and action plan of their creating shared value activities via various marketing channels, such as mass media and social network services.

\section{Conclusions}

The findings of the present study revealed that sport fans' perceptions toward a Korean professional sport team's creating shared value program had positive impacts on team trust and fan loyalty. In other words, as sport fans are aware of creating a shared value campaign of a professional sport team and perceive that it benefits the local community as well as the team, they are likely to enhance team trust and strengthen their loyalty toward the team. Therefore, for a successful creating shared value project, a professional sport team needs to inform fans of the team's creating shared value program, such as purpose, duration, and expected positive outcomes, through communication campaigns using local media. Meanwhile, the current study has several limitations that should be addressed. First, the present study explored the effects of a sport team's creating shared value activity on team trust and fan loyalty by utilizing the sample of the professional volleyball fans in South Korea, limiting the findings' generalizability. There has been a lack of knowledge established concerning consumers' perceptions toward creating shared value and consumption behaviors in the context of Korean professional sport teams such as professional volleyball [58] and basketball teams [59]. As such, future research should consider a population of sport fans in other professional sports to enhance the external validity of the tested model. Second, the current study did not consider consumers' experience value and consumption value, which are presented as the antecedents of consumers' perceived, creating shared value [60-62]. Thus, it would be appropriate to conduct follow-up studies considering these variables.

Author Contributions: Conceptualization, S.-s.K.; methodology, S.-s.K., W.-y.B., K.K.B., S.-b.J.; formal analysis, data curation, S.-s.K.; writing-original draft preparation, S.-s.K.; writing-review and editing, S.-s.K., W.-y.B., K.K.B., S.-b.J.; supervision, K.K.B. All authors have read and agreed to the published version of the manuscript.

Funding: This research was supported by the Bisa Research Grant of Keimyung University in 2018.

Conflicts of Interest: The authors declare no conflict of interest.

\section{References}

1. Public Affairs Council. 2014 Public Affairs Pulse Survey. 2014. Available online: http://pac.org/pulse/?p=298 (accessed on 5 March 2020).

2. Nielsen Global Research. Doing Well by Doing Good. 2014. Available online: https://www.nielsen.com/us/ en/insights/report/2014/doing-well-by-doing-good/ (accessed on 2 March 2020).

3. KPMG. The KPMG Survey of Corporate Responsibility Reporting 2017: The Road Ahead. 2017. Available online: https://assets.kpmg/content/dam/kpmg/xx/pdf/2017/10/kpmg-survey-of-corporate-responsibilityreporting-2017.pdf (accessed on 3 April 2020).

4. Barone, M.J.; Miyazaki, A.D.; Taylor, K.A. The Influence of Cause-Related Marketing on Consumer Choice: Does One Good Turn Deserve Another? J. Acad. Mark. Sci. 2000, 28, 248-262. [CrossRef] 
5. Lantos, G.P. The boundaries of strategic corporate social responsibility. J. Consum. Mark. 2001, 18, $595-632$. [CrossRef]

6. Porter, K.; Kramer, M.R. Creating shared value. Harv. Bus. Rev. 2011, 89, 62-77. [CrossRef]

7. Yoon, K.; Lee, E. A comparative study on the effects of CSR and CSV: The Moderating role of self-efficacy and message involvement. Korean J. Advert. 2014, 25, 53-72. [CrossRef]

8. Galzer, A.; Kannianinen, V.; Poutvaara, P. Firm's ethics, consumer boycotts and signaling. In Proceedings of the CESifo Ethics and Economics Conference, Munich, Germany, 19 May 2008; Center for Economic Studies and ifo Institute: Munich, Germany, 2008; p. 2323.

9. Hess, D.; Rogovsky, N.; Dunfee, T.W. The next wave of corporate community involvement: Corporate social initiatives. Calf. Manag. Rev. 2002, 44, 110-125. [CrossRef]

10. Ilyosisa. The Aftermath of the Food Industry Crushed by the Owner's Risk. Available online: http: //www.ilyosisa.co.kr/news/articleView.html?idxno=204915 (accessed on 20 March 2020).

11. Kim, K.; Lim, S. A study of effect that exhibition-convention center's creating shared value activities on corporate identification, corporate reputation, brand attitude. Korea Assoc. Trade Exhib. Stud. 2019, 14, 1-23. [CrossRef]

12. Park, S.; Kang, S.; Lee, S. The influence of creating shared value activities of food service corporations on corporate image, corporate credibility, consumer attitude and purchasing intention. J. Food. Manag. 2018, 21, 53-75.

13. An, S.; Han, J. A study on the impacts of hotel's CSV on corporate image, reliability and customer loyalty. Int. J. Hosp. Manag. 2016, 30, 135-149. [CrossRef]

14. Kang, H. Customer's social value perception and enterprise's sustainability: Focus on social enterprise. J. Mark. Thought 2017, 4, 71-77. [CrossRef]

15. Lee, D.; Moon, J.; Choe, Y.; Jeong, J. Impacts of socially responsible corporate activities on Korean consumers' corporate evaluations in the agrifood industry. Sustainability 2016, 8, 1292. [CrossRef]

16. Won, A.; Jung, D. Effects of company's creating shared value activities on non-financial management performance. J. Bus. Res. 2019, 34, 161-194.

17. Jin, C. The effects of creating shared value (CSV) on the consumer self-brand connection: Perspective of sustainable development. Corp. Soc. Responsib. Environ. Manag. 2018, 25, 1246-1257. [CrossRef]

18. Na, M.; Lee, J.; Han, J. The effects of creating shared value on brand loyalty: Focusing on the mediating effects of hotel image. J. Tour. Leis. Res. 2019, 31, 421-441. [CrossRef]

19. Lavack, A.M.; Kropp, F. A cross-cultural comparison of consumer attitudes toward cause related marketing. Soc. Mark. Q. 2003, 9, 3-16. [CrossRef]

20. Vlachos, A.P. Corporate Social Responsibility and Consumer-Firm Emotional Attachment: Moderating Effects of Consumer Traits. Eur. J. Mark. 2012, 46, 1559-1581. [CrossRef]

21. Mowen, J.C.; Sujan, H. Volunteer behavior: A hierarchical model approach for investigating its trait and functional motive antecedents. J. Consum. Psychol. 2005, 15, 170-182. [CrossRef]

22. Adomaviciute, K.; Bzikadze, G.; Cherian, J.; Urbonavicius, S. Cuase-related marketing as a commercially and socially oriented activity: What factors influence and moderate the purchasing? Eng. Econ. 2016, 27, 578-585. [CrossRef]

23. ICIC. What Does Shared Value Look Like for Sport Franchises? Available online: https://icic.org/blog/sharedvalue-look-like-sport-franchises/ (accessed on 20 March 2020).

24. Chosun.com. SK Knights Recruits 1st' Silver Challenger' to Create Jobs for Silver Generation. Available online: http://news.chosun.com/site/data/html_dir/2017/08/22/2017082201295.html (accessed on 20 March 2020).

25. Chosun.com. When the CEO Moves, the Company Changes. Available online: http://futurechosun.com/ archives/14020 (accessed on 21 March 2020).

26. Adidas. Five Years of Working with Parley to End Plastic Waste. Available online: https://news.adidas.com/parley-ocean-plastic/five-years-of-working-with-parley-to-end-plastic-waste/s/ 40d88ae9-a487-4dbf-af48-9ebb16882247 (accessed on 21 March 2020).

27. Becerra-Vicario, R.; León-Gómez, A.; Gutiérrez-Ruiz, A.M.; Fernández-Gámez, M.A. Sustainable development through corporative social responsibility, corporative philanthropy and creating shared vale. Tech. Soc. Sci. J. 2020, 10, 291-298.

28. Wójcik, P. How creating shared value differs from corporate social responsibility. J. Manag. Bus. Adm. Cent. Eur. 2016, 24, 32-55. [CrossRef] 
29. Fernández-Gámez, M.A.; Gutiérrez-Ruiz, M.A.; Becerra-Vicario, R.; Ruiz-Palomo, D. The effects of creating shared value on the hotel performance. Sustainability 2019, 11, 1784. [CrossRef]

30. Ham, S.; Lee, S.; Yoon, H.; Kim, C. Linking creating shared value to customer behaviors in the food service context. J. Hosp. Tour. Manag. 2020, 43, 199-208. [CrossRef]

31. Nam, S.; Hwang, H. What makes consumers respond to creating shared value strategy? Considering consumers as stakeholders in sustainable development. Corp. Soc. Responsib. Environ. Manag. 2019, 26, 388-395. [CrossRef]

32. Mercedes-Benz Stadium. The Equal Business Opportunity Plan. Available online: https://mercedesbenzstadium. com/ebo-plan/ (accessed on 21 March 2020).

33. NEWSIS. Hyundai Capital Volleyball Team Signed a Business Agreement with Chungnam Contents Business Development Center. Available online: https://newsis.com/view/?id=NISX20190223_0000567582 (accessed on 20 March 2020).

34. Park, S.; Lee, J. A study on the effects of creating shared value of airline on corporate image, trust, and behavioral intention. J. Hotel Resort 2016, 15, 361-380.

35. Lee, N. The Effect of Creating Shared Value through Improved Corporate Image and Trust on Customer Loyalty. Master's Thesis, Chung-Ang University, Seoul, Korea, 28 February 2016. Unpublished Work.

36. Keller, K.L. Conceptualizing, measuring and managing customer-based brand equity. J. Mark. 1993, 57, 1-22. [CrossRef]

37. Fombrun, C.; Shanley, M. What's in a name? Reputation building and corporate strategy. Acad. Manag. J. 1990, 233-258. [CrossRef]

38. Kramer, R.M. Trust and distrust in organizations: Emerging perspectives, enduring questions. Annu. Rev. Psychol. 1999, 50, 569-598. [CrossRef] [PubMed]

39. Lusch, R.; Brown, S.W.; Brunswick, G.J. A general framework for explaining internal vs. external exchange. J. Acad. Mark. Sci. 1992, 20, 119-134. [CrossRef]

40. Aaker, D.A. Managing Brand Equity: Capitalizing on the Value of Brand Name; The Free Press: New York, NY, USA, 1991.

41. Oliver, R.L. Whence consumer loyalty? J. Mark. 1999, 63, 33-44. [CrossRef]

42. Zeithaml, V.A.; Bitner, M.J. Services Marketing; McGraw-Hill: New York, NY, USA, 1996.

43. Moon, S.; Kim, J. The effect of corporate social responsibilities and creating shared value on cognitive/emotional trust and loyalty: Focused on the discount stores. Korea Res. Acad. Distrib. Manag. 2016, 19, 37-49. [CrossRef]

44. Kwon, H.; Han, J. A cause related marketing through sport: The effect of team identification and altruism on brand attitude. Korean J. Sport Mark. 2009, 14, 13-25.

45. Price, L.L.; Lawrence, F.F.; Audrey, G. Everyday market helping behavior. J. Public Policy Mark. 1995, 14, 255-266. [CrossRef]

46. Straughan, R.D.; Roberts, J.A. Environmental segmentation alternatives: A look at green consumer behavior in the new millennium. J. Consum. Mark. 1999, 16, 558-578. [CrossRef]

47. Gupta, S.; Pirsch, J. A taxonomy of cause-related marketing research: Current findings and future research directions. J. Nonprofit Public Sect. Mark. 2006, 15, 25-43. [CrossRef]

48. Seo, C. A study on the influence of the CSV of tourism business on the image, reliability, and action intention of business. J. Tour. Leis. Res. 2016, 28, 25-44.

49. Kim, S.; Byon, K.K.; Yu, J.; Zhang, J.J.; Kim, J. Social motivations and consumption behavior of spectators attending a formula one motor-racing event. Soc. Behav. Pers. 2013, 41, 1359-1378. [CrossRef]

50. Rushton, J.P.; Chrisjohn, R.D.; Fekken, G.C. The altruistic personality and the self-report altruism scale. Pers. Individ. Differ. 1981, 50, 1192-1198. [CrossRef]

51. Hair, J.F.; Black, W.C.; Babin, B.J.; Anderson, R.E. Multivariate Data Analysis, 7th ed.; Prentice Hall: Upper Saddle River, NJ, USA, 2010.

52. Fornell, C.; Larcker, D. Evaluating structural equation models with unobservable variables and measurement error. J. Mark. Res. 1981, 18, 39-50. [CrossRef]

53. Kim, Y.; Kim, E.; Kim, J. A study on the impact of CSV of delivery companies on confidence and intention to use delivery service: Focused on senior parcel delivery service. J. Korea Ind. Inf. Syst. Soc. 2017, 22, 85-100.

54. Park, B.; Kim, D. CJ Cheil-Jedang's com-prosperity programs based on creating shared value (CSV) perspective. Korea Bus. Rev. 2013, 17, 73-99.

55. Doney, P.M.; Cannon, J.P. An examination of the nature of trust in buyer-seller relationships. J. Mark. 1997, $61,35-51$. 
56. Kabadayi, E.T.; Alan, A.K. Brand trust and brand affect: Their strategic importance on brand loyalty. J. Glob. Strateg. Manag. 2012, 1, 80-88. [CrossRef]

57. Felman, J.M.; Lynch, J.G. Self-generated validity and other effects of measurement on belief, attitude, intention and behavior. J. Appl. Psychol. 1981, 18, 39-50. [CrossRef]

58. Jung, S. The Structural Relationship among the Creation of Shared Values for Professional Volleyball Team and the Club Trust, Club Emotion, Club Images, and the Spirit of Community. Ph.D. Thesis, Dankook University, Kyonggi, Korea, 13 June 2019. Unpublished Work.

59. Kim, S. The Effect of Professional Basketball Team's Creating Shared Value (CSV) on Team Image, Attitude toward Team, Team Reputation and Revisit Intention. Master's Thesis, Dankook University, Kyonggi, Korea, 30 May 2019. Unpublished Work.

60. Kim, G.; Chang, D. Structural relationship between experience value, creating shared value, brand image and brand loyalty in corporate complex culture space. J. Brand Des. Assoc. Korea 2018, 33-44. [CrossRef]

61. Lee, D.; Cianfrone, B.; Byon, K.K.; Schoenstedt, L. Examination of the relationships among personal values, team identification, product involvement, product attributes, and purchase intention of licensed team merchandise. Int. J. Sport Manag. 2010, 11, 517-540.

62. Jones, C.W.; Byon, K.K.; Huang, H.R. Service quality, perceived value, and fan engagement: Case of Shanghai Formula One racing. Sport Mark. Q. 2019, 28, 63-76. [CrossRef]

(C) 2020 by the authors. Licensee MDPI, Basel, Switzerland. This article is an open access article distributed under the terms and conditions of the Creative Commons Attribution (CC BY) license (http://creativecommons.org/licenses/by/4.0/). 